\title{
PENGEMBANGAN MODUL BERBASIS DISCOVERY LEARNING MATERI STRUKTUR DAN FUNGSI JARINGAN TUMBUHAN SMA
}

\author{
Nurhasikin $^{1 *}$, Kurnia Ningsih ${ }^{2}$, Titin Titin ${ }^{3}$ \\ ${ }^{1,2,3}$ Program Studi Pendidikan Biologi Fakultas Keguruan dan Ilmu Pendidikan Universitas \\ Tanjungpura, Jalan Prof. Dr. Hadari Nawawi Pontianak Kalimantan Barat Indonesia \\ *nurhasikin97bio@gmail.com
}

\section{Received: 26 Agustus 2019 Accepted: 1 Desember 2019 Published: 31 Desember 2019}

\begin{abstract}
Abstrak
Penelitian ini bertujuan untuk mengetahui kelayakan dan respon siswa terhadap modul berbasis discovery learning materi struktur dan fungsi jaringan tumbuhan. Metode yang digunakan Research and Development mengacu pada Borg \& Gall yang dimodifikasi menjadi 7 tahapan meliputi penelitian dan pengumpulan data, perencanaan, pengembangan draft produk, uji coba lapangan awal, revisi hasil uji coba, uji coba lapangan dan revisi produk operasional. Sampel penelitian adalah siswa SMAN 4 Pontianak, MAN 2 Pontianak dan SMA Mujahidin, dengan uji coba lapangan awal berjumlah 9 orang, sedangkan uji coba lapangan utama berjumlah 36 orang. Hasil validasi modul dari setiap aspek kelayakan isi, kebahasaan, sajian, dan kegrafisan memperoleh nilai sebesar 1,00 dengan kriteria sangat valid. Hasil respon uji coba lapangan awal sebesar 81,73\%, dan uji coba lapangan utama 82,16\%. Dapat disimpulkan bahwa modul berbasis discovery learning layak digunakan sebagai bahan ajar pada materi struktur dan fungsi jaringan tumbuhan dan mendapatkan respon dengan kategori sangat kuat.
\end{abstract}

Kata kunci: modul berbasis discovery learning, struktur dan fungsi jaringan tumbuhan, respon, kelayakan

\section{Abstract}

The study aims to determine the feasibility and response of students to the module-based discovery learning structure material and plant tissue function. The methods used by research and Development refer to the Borg \& Gall modified into 7 phases covering research and data collection, planning, product draft development, initial field trials, revision of trial results, field trials and operational product revisions. The research samples are the students of SMAN 4 Pontianak, MAN 2 Pontianak and Mujahidin High School, with an initial field trial of 9 people, while the main field trials amounted to 36 people. The result of module validation of every aspect of content eligibility, linguistic, servings, and graffiti obtained a value of 1.00 with very valid criteria. The results of the initial field trial response amounted to $81.73 \%$, and the main field trial was 82.16\%. It can be concluded that the discovery learning-based module deserves use as a teaching material on the structure material and plant tissue function and get a response with a very strong category.

Keywords: discovery learning-based module, structure and function of plant tissues, response, eligibility

(C) 2019 LPPM IKIP PGRI Pontianak, Indonesia

\section{PENDAHULUAN}

Belajar merupakan suatu proses yang dilakukan dengan cara berinteraksi dengan lingkungan untuk membentuk suatu perubahan dalam diri siswa pada aspek kognitif, afektif dan psikomotorik 
(Purwanto, 2009). Proses pembelajaran harus melibatkan adanya siswa dan adanya tenaga pengajar yaitu guru. Guru sebagai pengajar dapat memberikan pembelajaran, salah satunya dengan menggunakan sumber belajar seperti bahan ajar. Untuk menciptakan pembelajaran yang lebih efektif, efisien sesuai dengan kompetensi yang ingin dicapai maka peran guru sangat penting untuk melakukan pengembangan bahan ajar (Widyaningrum, dkk. 2013).

Bahan ajar merupakan segala bentuk bahan yang digunakan untuk membantu guru dalam melaksanakan kegiatan belajar mengajar dikelas (Amri \& Ahmadi, 2010). Bahan ajar yang dimaksud berupa bahan ajar tertulis maupun bahan ajar tidak tertulis (Amri ,2010). Adapun fungsi bahan ajar bagi guru yaitu sebagai pedoman yang akan mengarahkan semua aktivitasnya dalam proses pembelajaran dan merupakan substansi yang semestinya diajarkan kepada siswa, selain dapat meningkatkan pembelajaran lebih aktif dan interaktif. Fungsi bahan ajar bagi siswa yaitu: kegiatan pembelajaran menjadi lebih menarik, siswa lebih banyak mendapatkan kesempatan untuk belajar secara mandiri dengan bimbingan pendidik (Prastowo, 2014). Bahan ajar yang sering digunakan dalam proses pembelajaran adalah bahan ajar cetak, karena paling mudah diperoleh dan lebih sederhana, mudah digunakan, mudah dibaca oleh penggunanya (Belawati, dkk. 2007), selain itu bahan ajar cetak relatif murah untuk diproduksi atau dibeli dan dapat digunakan berulang-ulang, salah satunya adalah modul. Menurut Prastowo (2014) modul adalah sebuah bahan ajar yang disusun secara sistematis dengan bahasa yang mudah dipahami oleh peserta didik sesuai dengan tingkat pengetahuan dan usia mereka, agar mereka dapat belajar sendiri (mandiri) dengan bantuan atau bimbingan yang minimal dari pendidik.

Sejalan dengan perkembangan kurikulum 2013 yang menuntut peserta didik untuk dapat menguasai tujuan pembelajaran yang dapat dikategorikan dalam tiga ranah yaitu kognitif, afektif dan psikomotorik. Penerapan modul pembelajaran pada kurikulum 2013 juga menekankan pada pentingnya peserta didik bersikap ilmiah dan berperan aktif dalam menemukan sendiri konsep atau prinsip yang sebelumnya belum peserta didik temukan (Kurniawan, dkk. 2015). Untuk mewujudkan hal tersebut maka perlunya suatu model pembelajaran yang diterapkan oleh guru kepada peserta didiknya salah satunya dengan menerapkan pembelajaran berbasis discovery learning. Model discovery learning merupakan salah satu model pembelajaran konstruktivis yang memberi peluang kepada siswa untuk mencari dan menemukan sendiri konsep dengan menggunakan pendekatan pemecahan masalah (Priyayi, dkk. 2014).

Berdasarkan wawancara yang dilakukan pada ketiga sekolah yaitu di SMA Mujahidin Pontianak tanggal 19 Januari 2018, MAN 2 Pontianak tanggal 24 Januari 2018 dan SMA Negeri 4 Pontianak tanggal 26 Januari 2018 diperoleh informasi dari ketiga sekolah. Satu sekolah belum pernah menggunakan modul (MAN 2 Pontianak), sedangkan dua sekolah sudah pernah 
menggunakan modul (SMA Mujahidin Pontianak dan SMA Negeri 4 Pontianak). Ketiga guru mengungkapkan bahwa siswa mengalami kesulitan belajar pada materi jaringan tumbuhan yakni pada struktur dari masing-masing jaringan tumbuhan, fungsi dari masing-masing jaringan. Siswa sulit untuk mengingat konsep karena pada materi jaringan tumbuhan ini sangat banyak dan siswa sulit dalam menghafal/ mengingat perbedaan antara jaringan yang satu dengan yang lainnya. Selain itu, juga didukung dengan data nilai ulangan harian materi struktur dan fungsi jaringan tumbuhan di MIA 3 MAN 2 Pontianak dengan rata-rata nilai sebesar 68,83 yang belum mencapai KKM yakni 75. Penelitian Kusumawati (2016) mengungkapkan di SMA Negeri 3 Klaten bahwa siswa yang mempelajari materi struktur dan fungsi jaringan tumbuhan mengalami kesulitan diantaranya banyaknya konsep-konsep yang harus dipahami.

Mengingat materi struktur dan fungsi jaringan tumbuhan yang sulit untuk dikuasai oleh siswa yaitu ditandai dari banyaknya nilai siswa yang tidak mencapai ketuntasan. Bahan ajar yang digunakan guru yaitu buku teks dan LKS, selain bahan ajar guru juga menggunakan media pembelajaran seperti powerpoint dan video. Hasil dari wawancara dan observasi di SMAN 4 Pontianak bahwa guru sudah menggunakan modul namun belum memuat komponen-komponen secara lengkap, seperti tidak adanya petunjuk penggunaan modul, deskripsi tentang modul, glosarium dan evaluasi. Menurut Daryanto (2014) bahwa komponen yang terdapat dalam modul terdiri dari judul, kata pengantar, daftar isi, peta konsep, petunjuk penggunaan modul, kompetensi dasar, tujuan pembelajaran, materi, lembar kegiatan siswa, soal evaluasi, glosarium dan daftar pustaka.

Berdasarkan uraian diatas pentingnya bahan ajar tambahan berupa modul berbasis discovery learning yang valid dan praktis pada materi struktur dan fungsi jaringan tumbuhan, sehingga dapat membantu peserta didik dalam proses pembelajaran biologi di kelas XI SMA/ MA dan untuk mengetahui respon siswa dalam penggunaan modul.

\section{METODE}

Metode penelitian yang digunakan adalah penelitian research and development (R \& D). Menurut Sukmadinata (2011), metode penelitian dan pengembangan atau research and development adalah suatu proses atau langkah-langkah untuk mengembangkan suatu produk baru atau menyempurnakan produk yang telah ada, yang dapat dipertanggungjawabkan. Prosedur pengembangan dari penelitian adalah model prosedural yang dimodifikasi dari model pengembangan Borg \& Gall (dalam Sukmadinta, 2011) yang terdiri dari 10 tahapan, namun pada penelitian ini dilakukan hanya sampai pada tahap ketujuh yakni (1) penelitian dan pengumpulan data (research and information collection), (2) perencanaan (planning), (3) pengembangan draft produk (develop 
preliminary form of product), (4) uji coba lapangan awal (preliminary field testing), (5) revisi hasil uji coba (main product revision), (6) uji coba lapangan (main field testing), (7) penyempurnaan produk hasil uji coba lapangan (operasional product revision).

Dapat dijelaskan tahapan penelitian dan pengembangan ini adalah: 1) penelitian dan pengumpulan data, yaitu meliputi: studi literatur dan studi lapangan yaitu observasi di lapangan, wawancara, dan persiapan untuk merumuskan kerangka kerja penelitian; 2) perencanaan merupakan tahap penyusunan rencana penelitian yang meliputi, merumuskan tujuan penggunaan produk, menentukan penggunaan produk, mendeskripsikan komponen-komponen produk yang dikembangkan dan proses pengembangannya; 3) mengembangkan draft produk, termasuk dalam langkah ini adalah memberikan penilaian atau memvalidasi produk oleh validator, yang terdiri dari dua orang dosen program studi pendidikan biologi FKIP Untan; 4) melakukan uji coba lapangan awal dalam skala terbatas, melibatkan 3 sekolah dengan jumlah 9 subyek. Pengumpulan dan analisis data dilakukan dengan meminta peserta didik mengisi angket respon; 5) revisi hasil uji coba lapangan awal. Revisi ini dilakukan sesuai dengan hasil yang ditunjukkan dalam uji coba lapangan awal, sehingga diperoleh produk (modul) utama yang siap diuji coba lebih luas (uji coba lapangan utama); 6) uji lapangan utama yang juga melibatkan 3 sekolah, dengan jumlah subyek 36 siswa. Pengumpulan dan analisis data dilakukan dengan meminta peserta didik mengisi angket respon.; 7) revisi produk operasional.

Instrumen yang digunakan yaitu lembar validasi bahan ajar dan angket respon siswa. Lembar validasi ini meliputi empat aspek, yaitu kelayakan isi, kebahasaan, sajian, dan kegrafisan (Depdiknas, 2008). Hasil validasi modul oleh validator akan dihitung menggunakan rumus validitas isi (Gregory, 2011) pada Persamaan 1.

$$
V_{i}=\frac{D}{A+B+C+D}
$$

Angket respon siswa yang merupakan angket tertutup, yang terdiri dari tiga dimensi yaitu kognitif, afektif dan konatif serta menggunakan skala Likert dengan empat skala penilaian (kriteria), yaitu SS (sangat setuju), S (setuju), TS (tidak setuju), dan STS (sangat tidak setuju) (Riduwan, 2010). Angket ini dibuat dengan dua pernyataan, yaitu pernyataan positif dan pernyataan negatif. Analisis respon, dengan menghitung persentase perolehan skor total per item dengan Persamaan 2.

$$
P=\frac{\sum x}{\sum x l} \times 100 \%
$$

Pada Persamaan 2, diketathui bahwa $\mathrm{P}$ adalah persentase perolehan skor, $\sum x$ adalah jumlah perolehan skor (skor total) tiap item dan $\sum x l$ adalah jumlah skor ideal (skor tertinggi). 


\section{HASIL DAN PEMBAHASAN}

Validasi modul berbasis discovery learning pada materi struktur dan fungsi jaringan tumbuhan dilakukan untuk melihat tingkat validitas produk dan memberikan masukan untuk perbaikan. Hasil validasi modul struktur dan fungsi jaringan tumbuhan berbasis discovery learning disajikan pada Tabel 1.

Tabel 1. Hasil validasi modul oleh dua orang validator

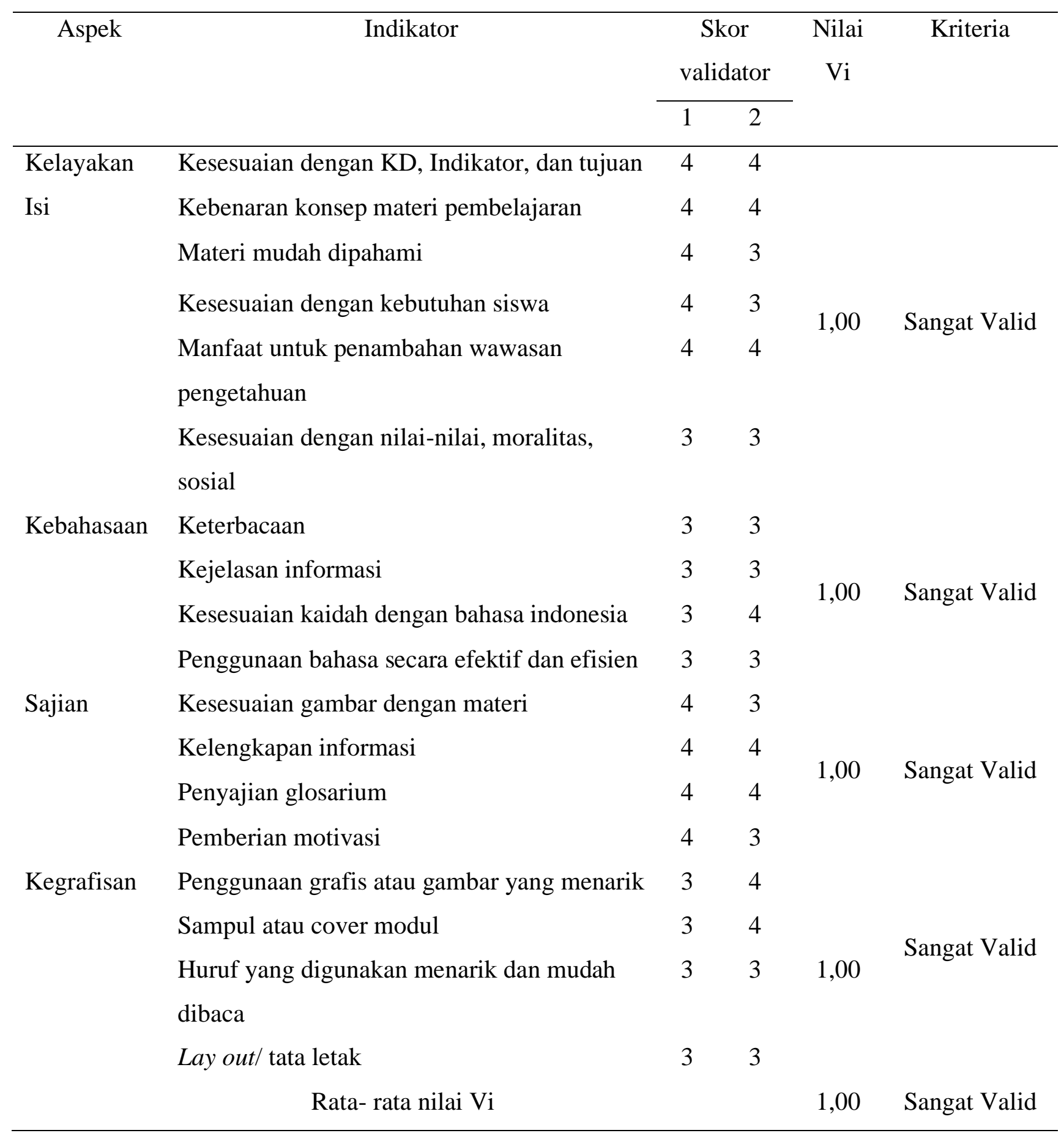


Pada Tabel 1, diperoleh informasi modul berbasis discovery learning pada materi struktur dan fungsi jaringan tumbuhan dinyatakan sangat valid dengan rata-rata nilai untuk tiap aspeknya sebesar 1,00, artinya modul berbasis discovery learning ini sangat layak digunakan sebagai bahan ajar.

Kegiatan berikutnya melihat respon siswa yang terdiri atas tiga dimensi yakni dimensi kognitif, yang terdiri atas tiga indikator meliputi kemudahan memahami materi di dalam modul, kesesuaian tampilan modul, dan kejelasan petunjuk belajar dan informasi di dalam modul. Dimensi afektif yang terdiri atas tiga indikator yakni motivasi, rasa ingin tahu dan kemenarikan. Dimensi konatif yang terdiri atas satu indikator yakni kecenderungan untuk melatih tahapan discovery learning. Respon ini diukur menggunakan angket setelah siswa mengerjakan modul berbasis discovery learning pada materi struktur dan fungsi jaringan tumbuhan. Hasil analisis angket respon siswa kelas XI SMAN 4 Pontianak, MAN 2 Pontianak dan SMA Mujahidin terhadap modul berbasis discovery learning pada uji coba lapangan awal dan uji coba lapangan utama dapat dilihat pada Tabel 2.

Tabel 2. Hasil analisis angket respon siswa pada uji coba lapangan awal

\begin{tabular}{|c|c|c|c|}
\hline \multirow{2}{*}{ Dimensi } & \multirow{2}{*}{ Indikator } & \multicolumn{2}{|c|}{ Respon Siswa } \\
\hline & & Skor $(\%)$ & Kriteria \\
\hline \multirow{3}{*}{ Kognitif } & $\begin{array}{l}\text { Kemudahan dalam memahami materi di dalam } \\
\text { modul }\end{array}$ & 82,22 & Sangat Kuat \\
\hline & Kesesuaian tampilan modul & 83,32 & Sangat Kuat \\
\hline & $\begin{array}{l}\text { Kejelasan petunjuk belajar dan informasi di dalam } \\
\text { modul }\end{array}$ & 80,25 & Kuat \\
\hline \multirow{4}{*}{ Afektif } & Rata-rata respon pada dimensi kognitif & 82,09 & Sangat Kuat \\
\hline & Motivasi & 80,11 & Kuat \\
\hline & Rasa ingin tahu & 84,49 & Sangat Kuat \\
\hline & Kemenarikan & 79,16 & Kuat \\
\hline \multirow{3}{*}{ Konatif } & Rata-rata respon pada dimensi afektif & 81,25 & Sangat Kuat \\
\hline & $\begin{array}{l}\text { Kecenderungan untuk melatih tahapan discovery } \\
\text { learning }\end{array}$ & 81,86 & Sangat Kuat \\
\hline & Rata-rata respon pada dimensi konatif & 81,86 & Sangat Kuat \\
\hline \multicolumn{2}{|c|}{ Rata-rata respon keseluruhan } & 81,73 & Sangat Kuat \\
\hline
\end{tabular}

Kesimpulan dari hasil analisis angket respon siswa terhadap modul berbasis discovery learning pada uji coba lapangan awal dengan sampel 9 orang peserta didik diperoleh rata-rata respon keseluruhan yakni $81,73 \%$ dengan kriteria sangat kuat. Berikutnya diperoleh hasil analisis angket 
respon siswa pada uji coba lapangan utama dengan sampel 36 orang peserta didik yang dapat dilihat pada Tabel 3.

Tabel 3. Hasil analisis angket respon siswa pada uji coba lapangan utama

\begin{tabular}{|c|c|c|c|}
\hline \multirow{2}{*}{ Dimensi } & \multirow{2}{*}{ Indikator } & \multicolumn{2}{|c|}{ Respon Siswa } \\
\hline & & Skor $(\%)$ & Kriteria \\
\hline \multirow{3}{*}{ Kognitif } & $\begin{array}{l}\text { Kemudahan dalam memahami materi di dalam } \\
\text { modul }\end{array}$ & 79,99 & Kuat \\
\hline & Kesesuaian tampilan modul & 84,19 & Sangat Kuat \\
\hline & $\begin{array}{l}\text { Kejelasan petunjuk belajar dan informasi di dalam } \\
\text { modul }\end{array}$ & 83,56 & Sangat Kuat \\
\hline \multirow{4}{*}{ Afektif } & Rata-rata respon pada dimensi kognitif & 82,28 & Sangat Kuat \\
\hline & Motivasi & 81,59 & Sangat Kuat \\
\hline & Rasa ingin tahu & 81,59 & Sangat Kuat \\
\hline & Kemenarikan & 82,98 & Kuat \\
\hline \multirow{3}{*}{ Konatif } & Rata-rata respon pada dimensi afektif & 82,05 & Sangat Kuat \\
\hline & $\begin{array}{l}\text { Kecenderungan untuk melatih tahapan discovery } \\
\text { learning }\end{array}$ & 82,17 & Sangat Kuat \\
\hline & Rata-rata respon pada dimensi konatif & 82,17 & Sangat Kuat \\
\hline \multicolumn{2}{|c|}{ Rata-rata respon keseluruhan } & 82,16 & Sangat Kuat \\
\hline
\end{tabular}

Kesimpulan dari hasil analisis angket respon siswa terhadap modul berbasis discovery learning pada uji coba lapangan utama dengan sampel 36 orang peserta didik diperoleh rata-rata respon keseluruhan yakni 82,16\% dengan kriteria sangat kuat.

\section{Validitas Modul Berbasis Discovery Learning pada Materi Struktur dan Fungsi Jaringan Tumbuhan}

Kelayakan modul struktur dan fungsi jaringan tumbuhan berbasis discovery learning dinyatakan sangat layak dengan nilai 1.00. hal ini dapat dilihat dari (Tabel 1) analisis data validasi modul pada aspek kelayakan isi, kebahasaan, sajian dan kegrafisan. Norlidah et.al. (2012), menyatakan bahwa modul yang didasarkan pada gaya pembelajaran yang tepat bisa menjadi paket yang efektif

\section{Aspek Kelayakan Isi}

Berdasarkan Tabel 1 dapat dilihat bahwa modul pada aspek kelayakan isi sudah dikatakan sangat valid dengan nilai Vi pada hasil validasi yakni 1.00. Pada aspek kelayakan isi terdiri atas enam indikator. Indikator pertama, kesesuaian dengan kompetensi dasar, indikator dan tujuan 
pembelajaran, kedua validator memberikan skor 4. Hal ini menunjukkan bahwa isi modul berbasis discovery learning pada materi struktur dan fungsi jaringan tumbuhan sudah sesuai dengan kompetensi dasar, indikator pembelajaran, dan tujuan pembelajaran. Indikator yang dirumuskan secara cermat dapat memberikan gambaran kegiatan pembelajaran yang efektif untuk pencapaian kompetensi (Dewi, 2015).

Indikator yang kedua yaitu kebenaran konsep materi pembelajaran, kedua validator memberikan skor 4. Hal ini berarti konsep materi yang ingin disajikan seluruhnya sudah sesuai dengan konsep struktur dan fungsi jaringan tumbuhan. Materi berupa konsep dan fakta penting yang terdapat di dalam modul akan mendukung pencapaian kompetensi yang harus dikuasai oleh siswa (Daryanto, 2014).

Indikator ketiga yaitu materi mudah dipahami. Materi yang disajikan pada modul berbasis discovery learning materi struktur dan fungsi jaringan tumbuhan ini mudah dipahami. Penilaian kedua validator terhadap indikator ini yaitu validator I memberikan skor 4 sedangkan validator II memberikan skor 3, yang termasuk dalam kategori relevan. Selain itu juga ada masukan dari guru bahwa kalimat atau bahasa di dalam modul berbasis discovery learning pada kegiatan praktikum dan beberapa konsep materi yang perlu dikonsistenkan. Menurut Asfiah, dkk (2013) bahwa penggunaan bahasa dalam modul seharusnya terhindar dari makna ganda sehingga siswa dapat lebih mudah dalam memahami informasi yang ingin disampaikan.

Indikator keempat yaitu kesesuaian dengan kebutuhan siswa. Penilaian masing-masing validator terhadap indikator ini yaitu validator I memberikan skor 4 sedangkan validator II memberikan skor 3. Modul berbasis discovery learning materi struktur dan fungsi jaringan tumbuhan disusun sesuai dengan kebutuhan siswa yang dilihat dari muatan materi, soal-soal formatif dan essay, soal evaluasi dan kegiatan praktikum. Hal ini sesuai dengan pendapat Sulistyani, dkk. (2013) yang menyatakan bahwa penilaian kemampuan pemahaman materi dapat dilakukan dengan mengerjakan soal-soal evaluasi. Hal ini juga didukung pernyataan Amri dan Ahmadi (2010) bahwa pengalaman belajar meliputi pertanyaan dalam modul berisi rincian materi untuk setiap tujuan pembelajaran khusus, diikuti dengan penilaian formatif sebagai balikan bagi siswa tentang tujuan belajar yang dicapainya. Indikator kelima yaitu manfaat untuk menambah wawasan pengetahuan. Pada indikator ini, kedua validator memberikan skor 4. Hal ini juga menunjukkan bahwa modul berbasis discovery learning materi struktur dan fungsi jaringan tumbuhan bermanfaat dan dapat menambah wawasan pengetahuan bagi peserta didik.

Indikator keenam yaitu kesesuaian dengan nilai-nilai, moralitas dan sosial. Pada indikator ini, masing-masing validator memberikan skor 3. Hal ini berarti isi, materi atau informasi yang terdapat di dalam modul berbasis discovery learning sudah cukup sesuai dengan nilai-nilai, moralitas dan 
sosial. Adapun masukan dari validator bahwa kesesuaian dengan nilai-nilai, moralitas dan sosial masih belum begitu terlihat didalam modul. Menurut Darkuni (dalam Leksono, dkk., 2015) menyatakan bahan ajar disusun berdasarkan capaian pembelajaran yang hendak dicapai, untuk menguasai disiplin ilmu, sebagai warisan nilai-nilai generasi ke generasi serta sesuai kebutuhan dan minat peserta didik.

\section{Aspek Kebahasaan}

Berdasarkan Tabel 1 dapat dilihat bahwa modul pada aspek kebahasaan sudah dikatakan sangat valid dengan nilai Vi pada hasil validasi yakni 1.00. Aspek kebahasaan terdiri atas empat indikator. Adapun indikator pertama dari aspek ini adalah keterbacaan. Pada indikator ini kedua validator memberikan skor 3. Hal ini berarti keseluruhan kosakata yang digunakan di dalam modul berbasis discovery learning cukup mudah dipahami oleh siswa namun masih terdapat 1-2 kosakata yang sulit untuk dipahami oleh siswa. Dengan memiliki tingkat keterbacaan yang tinggi serta sesuai dengan kemampuan siswa, maka suatu modul akan dapat membantu siswa dalam mencapai tujuan pembelajaran yang efektif dan efisien (Daryanto, 2014).

Indikator kedua yaitu kejelasan informasi. Penilaian kedua validator memberikan skor 3 yang juga termasuk kategori relevan. Hal ini berarti informasi di dalam modul berbasis discovery learning sudah jelas. Informasi di dalam modul harus jelas karena hal ini akan memudahkan peserta didik untuk bisa memahami isi materi dan petunjuk-petunjuk dalam menggunakan modul. Indikator ketiga yaitu kesesuaian kaidah dengan bahasa indonesia. Masing-masing validator memberikan skor yaitu validator I skor 3 sedangkan validator II skor 4. Namun demikian, skor 3 yang diberikan oleh validator 1 sudah termasuk kategori yang relevan artinya bahasa yang digunakan sudah cukup sesuai dengan PUEBI. Hal ini juga sesuai yang diungkapkan (Depdiknas, 2008) bahwa semua bahan ajar harus memperhatikan komponen kebahasaan sesuai dengan aspek dalam sub komponen kelayakan bahasa, sehingga ketepatan struktur kalimat dan susunan materi yang sistematis memudahkan siswa dalam memahami materi pembelajaran. Terdapat saran dari validator yaitu perbaiki pengetikan kalimat dalam modul. Indikator keempat yaitu penggunaan bahasa secara efektif dan efisien. Pada indikator ini masing-masing indikator memberikan skor 3. Hal ini berarti terdapat satu atau beberapa kalimat di dalam modul berbasis discovery learning yang tidak sesuai dengan PUEBI, adapun masukan dari guru biologi di sekolah bahwa masih ditemukan beberapa kalimat di dalam modul yang belum sesuai dengan PUEBI. Menurut Prastowo (2014) bahwa kalimat yang disajikan pada modul tidak boleh terlalu panjang, intinya sederhana, singkat jelas dan efektif sehingga siswa akan mudah memahaminya. 


\section{Aspek Sajian}

Berdasarkan Tabel 1 dapat dilihat bahwa modul pada aspek sajian sudah dikatakan sangat valid dengan nilai Vi pada hasil validasi yakni 1.00. Dalam hal ini penyajian bahan ajar yang mencakup semua komponen yang meliputi sistematika penyajian, keruntutan konsep, kesesuaian gambar/ilustrasi dengan materi, penyajian teks, gambar, rujukan atau sumber acuan, rangkuman, daftar pustaka dan glosarium (Daryanto, 2013). Aspek sajian terdiri atas empat indikator, untuk indikator pertama yakni kesesuaian gambar dengan materi, penilaian yang diberikan validator I dengan skor 4, sedangkan validator II memberikan skor 3. Gambar yang disajikan dalam modul berbasis discovery learning materi struktur dan fungsi jaringan tumbuhan sudah sesuai dan cukup jelas. Dengan adanya gambar-gambar maka dapat mendukung dan memperjelas isi materi sehingga menimbulkan daya tarik dan mengurangi kebosanan bagi pembaca (Prastowo, 2014). Selain itu, Burger, et.al (2002) menyatakan bahwa metode yang dapat digunakan untuk meningkatkan kejelasan pada pembelajaran adalah melalui penyampaian materi sesederhana mungkin sesuai dengan tingkat perkembangan peserta didik dan mengaitkannya dengan pengetahuan yang peserta didik ketahui. Indikator kedua yaitu kelengkapan informasi. Penyajian informasi yang lengkap dapat membuat pembacanya lebih memahami materi di dalam modul. Informasi yang dimaksud yakni berupa konsep dan cakupan materi, gambar serta ilustrasi yang jelas dan mendukung sehingga mudah dipahami oleh peserta didik. Pada indikator ini kedua validator memberikan skor 4. Hal ini berarti informasi yang terdapat di dalam modul struktur dan fungsi jaringan tumbuhan berbasis discovery learning sudah lengkap dan dapat membantu peserta didik dalam belajar mandiri.

Indikator ketiga yaitu penyajian glosarium, kedua validator memberikan skor 4. Glosarium memuat definisi operasional yang digunakan dalam modul dan sering diperlukan oleh pembaca (Prastowo, 2014). Sehingga dapat disimpulkan bahwa glosarium yang disajikan dapat membantu siswa memahami istilah-istilah asing yang terdapat pada materi yang disajikan di dalam modul berbasis discovery learning. Indikator keempat yaitu pemberian motivasi. Penilaian yang diberikan oleh validator I dengan skor 4 sedangkan validator II dengan skor 3. Pemberian motivasi dalam modul ini berupa stimulasi yang disampaikan disetiap awal kegiatan pembelajaran. Dengan stimulasi/stimulus tersebut siswa dapat termotivasi serta memiliki rasa ingin tahu yang tinggi untuk mempelajari materi berikutnya.

\section{Aspek Kegrafisan}

Berdasarkan Tabel 1 dapat dilihat bahwa modul pada aspek kegrafisan sudah dikatakan sangat valid dengan nilai Vi pada hasil validasi yakni 1.00. Kegrafisan yang dinilai dalam modul ini yaitu mencakup kemenarikan warna dan ilustrasi desain cover modul serta bagian isi modul, pesan dan gagasan yang disampaikan bahan ajar. Aspek kegrafisan terdiri atas empat indikator, indikator 
pertama yakni penggunaan grafis atau gambar yang menarik, validator I memberikan skor 3, sedangkan validator II memberikan skor 4. Sehingga dapat disimpulkan bahwa penggunaan grafis atau gambar pada modul sudah baik. Penggunaan grafis atau gambar yang menarik dapat memberikan stimulus yang optimal bagi siswa (Prastowo, 2014).

Indikator kedua yakni sampul atau cover modul, validator I memberikan skor 3, sedangkan validator II memberikan skor 4. Berdasarkan penilaian validator menunjukkan desain sampul sudah baik. Menurut Daryanto (2014) kombinasi warna, gambar, bentuk dan ukuran huruf yang serasi pada desain cover dapat menimbulkan daya tarik pada model. Indikator ketiga yaitu huruf yang digunakan menarik dan mudah dibaca, masing-masing validator memberikan skor 3. Hal ini berarti huruf yang digunakan dalam modul berbasis discovery learning ini sudah menarik namun masih terdapat beberapa huruf sulit dibaca, dan terdapat saran dari validator yaitu konsistensi penggunaan jenis dan ukuran huruf pada keterangan gambar. selain validator juga terdapat saran dan komentar dari guru bahwa di dalam modul berbasis discovery learning ini penggunaan jenis huruf tidak terlalu banyak dan variasi huruf tidak berlebihan agar lebih mudah dan tertarik untuk membaca. Hal tersebut sesuai dengan pernyataan Sari (2006) yang menyatakan pilihan huruf yang menarik dapat menambah ketertarikan pada peserta didik untuk membaca. Indikator keempat yaitu lay out, tata letak, penilaian yang diberikan masing-masing validator yakni skor 3. Hal ini berarti tata letak kalimat dan alenia dalam modul berbasis discovery learning sudah tepat namun masih terdapat komponen yang kurang tepat. Terdapat saran dari validator yaitu konsistensi dalam posisi peletakan gambar pada modul. Berdasarkan hasil validasi oleh validator tentang kelayakan modul, modul struktur dan fungsi jaringan tumbuhan berbasis discovery learning dinyatakan sangat layak dengan nilai 1.00.

\section{Respon Siswa Terhadap Modul Berbasis Discovery Learning Pada Materi Struktur dan Fungsi Jaringan Tumbuhan}

Pengumpulan data menggunakan angket respon untuk melihat tanggapan atau respon siswa terhadap modul berbasis discovery learning materi struktur dan fungsi jaringan tumbuhan. Respon siswa terdiri atas tiga dimensi yakni dimensi kognitif, dimensi afektif dan dimensi konatif. Angket respon terdiri dari 24 item pernyataan yang terdiri dari pernyataan positif dan negatif yakni pada dimensi kognitif yang terdiri dari 12 pernyataan, dimensi afektif terdiri dari 6 penyataan dan dimensi konatif terdiri dari 6 pernyataan.

\section{Uji Coba Lapangan Awal}

Respon siswa yang dilihat dalam penelitian ini terdiri atas tiga dimensi yakni dimensi kognitif, yaitu berhubungan dengan pemikiran atau persepsi seseorang tentang objek sikap. Hal ini dapat diidentifikasi dari ungkapan keyakinannya atas sesuatu (Amir, 2015). Diperoleh hasil rata-rata respon keseluruhan pada uji coba lapangan awal yakni sebesar 81,73 dengan kriteria sangat tinggi. 
Selanjutnya rata-rata respon siswa yang bersifat kognitif pada uji coba lapangan awal sebesar 82,09\% dengan kriteria sangat kuat. Adapun indikator pada kategori respon kognitif adalah sebagai berikut: Kemudahan memahami materi di dalam modul, kesesuaian tampilan modul, dan kejelasan petunjuk belajar dan informasi didalam modul. Kemudian respon afektif adalah respon yang menunjukkan sikap seseorang yang dapat disimpulkan dari perasaan seseorang atas objek sikapnya (Amir, 2015). Rata-rata respon siswa yang bersifat afektif sebesar 81,25\% dengan kriteria sangat kuat. Indikator pada kategori respon afektif adalah sebagai berikut: motivasi, rasa ingin tahu dan kemenarikan. Selanjutnya respon konatif yakni respon yang bersifat konatif terkait dengan kecenderungan perilaku, keinginan, dan tindakan yang terkait dengan objek sikap (Amir. 2015). Rata-rata respon siswa yang bersifat konatif sebesar 81,86\% dengan kriteria sangat kuat. Adapun indikator pada kategori respon konatif adalah kecenderungan untuk melatih tahapan discovery learning. Data respon siswa pada uji coba lapangan awal dipaparkan dalam bentuk tabel yang memuat nilai masing-masing butir pernyataan dan rata-rata nilai (Tabel 2).

\section{Uji Coba Lapangan Utama}

Diperoleh hasil rata-rata respon keseluruhan pada uji coba lapangan utama yakni sebesar 82,16\% dengan kriteria sangat kuat, bisa dilihat pada (Tabel 3).

\section{Respon Kognitif}

Rata-rata respon siswa yang bersifat kognitif pada uji coba lapangan utama sebesar 82,28\% dengan kategori sangat kuat. Pada respon kognitif ini terdapat tiga indikator yang dinilai yaitu kemudahan memahami materi dalam modul, kesesuaian tampilan modul dan kejelasan petunjuk belajar dan informasi dalam modul.

Materi merupakan salah satu komponen utama dalam suatu bahan ajar khususnya modul (Prabowo, dkk. 2016). Pada indikator pertama yaitu kemudahan memahami materi dalam modul terdiri atas lima pernyataan yaitu tiga pernyataan positif dan dua pernyataan negatif. Diperoleh ratarata skor pada indikator ini yaitu 79,99\% dengan kategori kuat. Hal ini menunjukkan bahwa materi yang disajikan di dalam modul discovery learning ini mudah untuk dipahami oleh siswa, hal ini didukung dengan diperolehnya nilai hasil dari pengerjaan soal-soal di dalam modul berbasis discovery learning materi struktur dan fungsi jaringan tumbuhan dimana untuk SMAN 4 Pontianak diperoleh rata-rata nilai sebesar 85,1, MAN 2 Pontianak diperoleh rata-rata nilai sebesar 84,5 dan SMA Mujahidin diperoleh rata-rata nilai sebesar 82,4. Selain itu, kemudahan dalam memahami materi ini juga di sertai dengan penyusunan bahasa serta kalimat yang baik dan benar sesuai dengan PUEBI. Hal ini sejalan dengan pernyataan Arsyad (2010) bahwa penggunaan bahasa yang baik dan benar dapat memperlancar pemahaman siswa dalam memahami hal yang dipelajari. Akan tetapi, skor pada indikator ini mengalami penurunan dibanding pada uji coba lapangan awal. Hal ini 
disebabkan oleh jumlah siswa yang besar pada uji coba lapangan utama sehingga mempengaruhi fokus siswa untuk bisa memahami materi yang dibaca di dalam modul berbasis discovery learning pada materi struktur dan fungsi jaringan tumbuhan.

Pada indikator kedua yaitu kesesuaian tampilan modul terdiri dari empat pernyataan yakni dua pernyataan positif dan dua pernyataan negatif. Diperoleh rata-rata skor pada indikator ini yaitu 84,19\% dengan kategori sangat kuat. Pada indikator ini mencakup kesesuaian isi materi dengan gambar, foto serta ilustrasi di dalam modul discovery learning. Materi atau konsep pada bahan ajar dapat disampaikan melalui teks, gambar, tabel atau urutan sesuai dengan jenis informasi yang disajikan (Pashler, et.al., 2007). Hal ini juga selaras yang diungkapkan oleh Prastowo (2014) yang menyebutkan tentang kegunaan modul dalam proses pembelajaran antara lain sebagai penyedia informasi dasar, karena di dalam modul disajikan berbagai materi pokok yang masih bisa dikembangkan lebih lanjut, sebagai bahan instruksi atau petunjuk bagi siswa serta sebagai bahan pelengkap dengan ilustrasi dan foto yang komunikatif. Selain gambar/foto yang harus sesuai dengan materi, tampilan warna atau variasi warna di dalam modul berbasis discovery learning juga harus menarik, hal ini sejalan dengan pendapat Ami, dkk. (2012) bahwa warna berperan memberikan suasana menyenangkan pada pembaca untuk membaca lebih lanjut isi materi.

Pada indikator ketiga yaitu kejelasan pentunjuk belajar dan informasi dalam modul terdiri dari tiga pernyataan yaitu dua pernyataan positif dan satu pernyataan negatif. Diperoleh rata-rata skor pada indikator ini yaitu 83,56\% dengan kategori sangat kuat. Hal ini berarti petunjuk belajar dan informasi didalam modul berbasis discovery learning sudah jelas dan mudah dipahami oleh peserta didik. Menurut Arsyad (2010) bahwa peserta didik akan memahami dan mengingat lebih lama materi/informasi yang disusun secara logis dan diurut-urutkan secara teratur.

\section{Respon Afektif}

Rata-rata respon siswa yang bersifat afektif sebesar 82,05\% dengan kategori sangat kuat. Adapun indikator yang dinilai pada kategori respon afektif ini adalah motivasi, rasa ingin tahu dan kemenarikan. Pada indikator motivasi terdiri dari satu pernyataan positif dan satu pernyataan negatif. Diperoleh rata-rata skor pada indikator ini sebesar 81,59\% dengan kategori sangat kuat. Hal ini menunjukkan bahwa modul berbasis discovery learning ini dapat memberikan motivasi bagi peserta didik untuk belajar materi struktur dan fungsi jaringan tumbuhan.

Pada indicator rasa ingin tahu terdiri dari dua pernyataan yakni satu pernyataan positif dan satu pernyataan negatif. Diperoleh rata-rata skor pada indikator ini yaitu 81,59\% dengan kategori sangat kuat. Hal ini berarti bahwa modul yang disajikan dengan unsur tahapan discovery learning serta percobaan untuk melakukan praktikum dapat menumbuhkan rasa ingin tahu siswa. 
Pada indikator kemenarikan terdiri dari dua pernyataan yakni satu pernyataan positif dan satu pernyataan negatif. Diperoleh rata-rata skor pada indikator ini yaitu 82,98\% dengan kategori sangat kuat. Hal ini berarti tampilan gambar, isi, informasi yang disajikan di dalam modul berbasis discovery learning menarik bagi siswa. Hal ini sejalan dengan pernyataan Syahroni (2016) bahwa tampilan gambar, font, kejelasan font dan desain tampilan lebih ditonjolkan sehingga menarik untuk mempelajarinya.

\section{Respon Konatif}

Rata-rata respon siswa yang bersifat konatif sebesar 82,17\% dengan kategori sangat kuat. Pada respon konatif ini terdiri dari satu indikator yakni kecenderungan untuk melatih tahapan discovery learning. Pada indikator ini terdiri dari enam pernyataan yakni tiga pernyataan positif dan tiga pernyataan negatif. Diperoleh rata-rata skor pada indikator ini yaitu 82,17\% dengan kategori sangat kuat. Pada indikator ini peserta didik dilatih untuk dapat menerapkan tahapan-tahapan discovery learning yang ada di dalam modul berbasis discovery learning diantaranya seperti membuat rumusan masalah, membuat stimulasi, membuat hipotesis, mengumpulkan data, membuat kesimpulan dan mengolah data. Hal ini didukung pernyataan Sagala dalam (Khabibah, dkk. 2014) bahwa dalam proses pembelajaran discovery siswa lebih banyak melakukan kegiatan sendiri, menemukan sendiri atau dalam kelompok memecahkan permasalahan. Hal ini selaras menurut Roestiyah dalam (Khabibah, dkk. 2014) bahwa dalam proses pembelajaran discovery siswa mampu mengasimilasikan suatu konsep atau prinsip, yakni mengamati, mencerna, mengerti, menggolong-golongkan, membuat dugaan/ hipotesis, dan membuat kesimpulan.

\section{SIMPULAN}

Berdasarkan hasil penelitian yang dilakukan dapat disimpulkan bahwa modul berbasis discovery learning pada materi struktur dan fungsi jaringan tumbuhan dinyatakan sangat valid dengan nilai rata-rata validasi sebesar 1.00, artinya modul berbasis discovery learning ini sangat layak digunakan sebagai bahan ajar. Kemudian respon siswa terhadap modul berbasis discovery learning pada materi struktur dan fungsi jaringan tumbuhan pada uji coba lapangan awal, memperoleh respon sebesar $81,73 \%$ dengan kriteria sangat kuat. Pada uji coba lapangan utama persentase respon sebesar $82,16 \%$ dengan kriteria sangat kuat.

\section{DAFTAR PUSTAKA}

Alias, N., Siraj, S., DeWitt, D., Attaran, M., \& Nordin, A. B. (2013). Evaluation on the usability of physics module in a secondary school in Malaysia: students' retrospective. Malaysian Online Journal of Educational Technology, 1(1), 44-53. 
Ami, M. S. (2012). Pengembangan buku saku materi sistem ekskresi manusia di SMA/MA Kelas XI. BioEdu, 1(2), 10-13.

Amir, M. T. (2015). Merancang kuesioner: konsep dan panduan untuk penelitian sikap, kepribadian dan perilaku. Jakarta: Prenadamedia Group.

Amri, S., \& Ahmadi, I. K. (2010). Konstruksi pengembangan pembelajaran pengaruhnya terhdap mekanisme dan pratek kurikulum. Jakarta: PT Prestasi Pustakaraya.

Arsyad, A. (2010). Media pembelajaran. Jakarta: PT. Raja Grafindo Persada.

Asfiah, N., Mosik, M., \& Purwantoyo, E. (2013). Pengembangan modul IPA terpadu kontekstual pada tema bunyi. Unnes Science Education Journal, 2(1), 188-195.

Belawati, T. S., Andayani, Julaeha, S., \& Pannen, P. (2007). Pengembangan bahan ajar. Jakarta: Universitas Terbuka.

Bulger, S. M., Mohr, D. J., \& Walls, R. T. (2002). Stack the dark in favor of your students by using the four aces of effective teaching. Journal of Effective Teaching, 5(2).

Daryanto. (2014). Menyusun modul: bahan untuk persiapan dalam mengajar. Yogyakarta: Gava Media.

Depdiknas. (2008). Panduan pengembangan bahan ajar. Jakarta: Depdiknas.

Dewi, N. (2015). Merancang pencapaian kompetensi dasar melalui perumusan indikator. Artikel EBuletin Edisi Maret 2015. ISSN. 2355-3189.

Gregory, R. J. (2011). Tes psikologi: sejarah, prinsip dan aplikasi. Jakarta: Erlangga.

Khabibah, E. N., Nur, K., \& Gatot, S. (2014). Validitas teoritis modul berbasis guided discovery pada materi respiratory system. Bioedu Berkala Ilmiah Pendidikan Biologi, 3(3), 589-593.

Kurniawan, G., Azrita, \& Muhar, N. (2015). Pengembangan modul berbasis saintifik model discovery learning pada materi sistem ekskresi manusia untuk siswa kelas XI SMA Negeri 1 Lembah Gumanti. Jurnal Bunghatta, 4(5), 1-15.

Kusumawati, M. U. (2016). Identifikasi kesulitan belajar materi struktur fungsi jaringan tumbuhan pada siswa SMA Negeri 3 Klaten kelas XI tahun ajaran 2015/2016. Jurnal Pendidikan Biologi, 5(7), 22-23.

Leksono, S. M., Syachruroji, A., \& Marianingsih, P. (2015). Pengembangan bahan ajar biologi konservasi berbasis etnopedagogi. Jurnal Pendidikan, 45(2), 168-183.

Pashler, H., Bain, P. M., Bottge, B. A., Graesser, A., Koedinger, K., McDaniel, M., \& Metcalfe, J. (2007). Organizing instruction and study to improve student learning. IES Practice Guide. NCER 2007-2004. National Center for Education Research. 
Prabowo, C. A., Ibrohim, I., \& Saptasari, M. (2016). Pengembangan modul pembelajaran inkuiri berbasis laboratorium virtual. Jurnal Pendidikan: Teori, Penelitian, dan Pengembangan, 1(6), 1090-1097.

Prastowo, A. (2014). Pengembangan bahan ajar tematik. Jakarta: Kencana.

Priyayi, D. F., \& Prayitno, B. A. (2014). Pengembangan model pembelajaran accelerated learning included by discovery (ALID) pada materi jaringan tumbuhan Kelas XI SMA Negeri 7 Surakarta. Inkuiri, 3(2), 1-15.

Purwanto. (2009). Evaluasi hasil belajar. Yogyakarta: Pustaka Belajar.

Riduwan, M. B. A. (2010). Dasar-dasar statistika. Bandung: Alfabeta.

Sari, M. A. (2016). Pengembangan media pembelajaran buku saku berbasis mind mapping materi sistem pemerintahan tingkat pusat untuk meningkatkan hasil belajar PKn KELAS IV SDN TAMBAKAJI 02 (Doctoral dissertation, Universitas Negeri Semarang).

Sukmadinata, N.S. (2011). Metode penelitian pendidikan. Bandung: PT Remaja Rosdakarya.

Sulistyani., Nurul, H. D., Jamzuri., \& Rahardjo, D.T. (2013). Perbedaan hasil belajar siswa antara menggunakan media pocket book dan tanpa pocket book pada materi kinematika gerak melingkar kelas X. Jurnal Pendidikan Fisika, 1 (1), 164-172.

Syahroni, M., Nurrochmah, S., \& Amiq, F. (2016). Pengembangan buku saku elektronik berbasis android tentang signal-signal wasit futsal untuk wasit futsal di kabupaten pasuruan. Pendidikan Jasmani. 26(2), 304-317.

Widyaningrum, R., Sarwanto, \& Karyanto, P. 2013. Pengembangan modul berorientasi Poe (Predict, Observe, Explain) berwawasan lingkungan pada materi pencemaran untuk meningkatkan hasil belajar siswa. Jurnal Bioedukasi, 6(1), 100-117 